\title{
A systematic review of pentacyclic triterpenes and their derivatives as chemotherapeutic agents against tropical parasitic diseases
}

\author{
MURTALA BINDAWA ISAH ${ }^{1,4} * \dagger$, MOHAMMED AUWAL IBRAHIM ${ }^{2}$, \\ AMINU MOHAMMED ${ }^{2}$, ABUBAKAR BABANDO ALIYU ${ }^{3}$, BUBUYA MASOLA ${ }^{4}$ and \\ THERESA H. T. COETZER ${ }^{5}$ \\ ${ }^{1}$ Department of Biochemistry, Umaru Musa Yar'adua University Katsina, Katsina, Nigeria \\ ${ }^{2}$ Department of Biochemistry, Ahmadu Bello University Zaria, Zaria, Nigeria \\ ${ }^{3}$ Department of Chemistry, Ahmadu Bello University Zaria, Zaria, Nigeria \\ ${ }^{4}$ Department of Biochemistry, School of Life Sciences, University of KwaZulu-Natal, Westville Campus, Durban, 4000, \\ South Africa \\ ${ }^{5}$ Department of Biochemistry, School of Life Sciences, University of KwaZulu-Natal, Pietermaritzburg Campus, \\ Scottsville, 3209, South Africa
}

(Received 12 Fanuary 2016; revised 28 March 2016; accepted 30 March 2016; first published online 31 May 2016)

\begin{abstract}
SUMMARY
Parasitic infections are among the leading global public health problems with very high economic and mortality burdens. Unfortunately, the available treatment drugs are beset with side effects and continuous parasite drug resistance is being reported. However, new findings reveal more promising compounds especially of plant origin. Among the promising leads are the pentacyclic triterpenes (PTs) made up of the oleanane, ursane, taraxastane, lupane and hopane types. This paper reviews the literature published from 1985 to date on the in vitro and in vivo anti-parasitic potency of this class of phytochemicals. Of the 191 natural and synthetic PT reported, 85 have shown high anti-parasitic activity against various species belonging to the genera of Plasmodium, Leishmania, Trypanosoma, as well as various genera of Nematoda. Moreover, structural modification especially at carbon 3 (C3) and C27 of the parent backbone of PT has led to improved anti-parasitic activity in some cases and loss of activity in others. The potential of this group of compounds as future alternatives in the treatment of parasitic diseases is discussed. It is hoped that the information presented herein will contribute to the full exploration of this promising group of compounds as possible drugs for parasitic diseases.
\end{abstract}

Key words: Pentacyclic triterpenes, anti-parasitic, Plasmodium, Leishmania, Trypanosoma, Nematoda.

\section{INTRODUCTION}

Tropical parasitic diseases have been a serious public health problem especially in middle- and low-income countries. These diseases which include malaria, trypanosomiasis, leishmaniasis, schistosomiasis, lymphatic filariasis and onchorcerciasis affect millions of people, resulting in thousands of death annually. The disability-adjusted life year lost estimate for these diseases is very high with a combined annual magnitude of more than 70 million by 2011 (Bhutta et al. 2014; Hotez et al. 2014). At present, there have been reports on the spread of parasitic infections in non-endemic areas which raised more concerns about the feasibility of the global control strategy (Leder et al. 2013). The main obstacles in the control of parasitic diseases are the drugs resistance,

* Corresponding author: Department of Biochemistry, Faculty of Natural and Applied Sciences, Umaru Musa Yaradua University, Katsina, Nigeria. Tel: +2348034651034. E-mail: dmurtalabdw@gmail.com

$\dagger$ Present address: Department of Biochemistry, School of Life Sciences, University of KwaZulu-Natal, Pietermaritzburg Campus, Scottsville, 3209, South Africa. Tel: +27846747187 . toxicity and non-affordability of the available drugs (Buckner et al. 2012). This has prompted a continuous search for safer and more effective treatments especially from natural sources. In this regard, plants have been a prime target for novel therapeutic agents as evident from the large volume of studies being conducted on medicinal plants documented in scientific databases (Rocha et al. 2005; Wright, 2010; Izumi et al. 2011; Ibrahim et al. 2014). Interestingly, considerable success has been recorded with about $65 \%$ of all anti-parasitic agents marketed from 1981 to 2010 being originally derived from plant sources and sometimes with synthetic modifications (Newman and Cragg, 2012). This further stimulates research activities on this important area to identify novel bioactive anti-parasitic agents that could potentially be used to combat tropical parasitic diseases. Fortunately, a number of bioactive agents, such as flavonoids, curcuminoids and triterpenoids have shown promising anti-parasitic activities that warrant further drug development studies (Rasoanaivo et al. 2011; Ibrahim et al. 2014).

Pentacyclic triterpenes (PTs) belong to a group of widespread isoprene-derived secondary metabolites 
collectively known as triterpenes (a sub-class of terpenes). PTs are synthesized mainly by the cyclization of oxidosqualene and squalene and exist in their free form or as components of saponins (glycosides) in many tropical and subtropical plants (Xu et al. 2004; Jäger et al. 2009). The compounds have attracted attention due to their remarkable biological activities. With regard to this, three groups of PT, namely; the oleanane, ursane and lupane groups are considered to be the most important (Dzubak et al. 2006), although other groups such as hopane, taraxastane and friedelane types may also be important. Thus, various derivatives of the biologically important groups of $\mathrm{P} T$ are synthesized with the aim of lowering the toxicity and/or increasing the therapeutic activity of the parent compounds. Some of these PT are already registered and/or being marketed in some parts of the world as clinical drugs for the treatment of liver related diseases and diabetes, while others are at various phases of clinical trials (Sheng and Sun, 2011).

Presently, update on the newly discovered PT is a subject of annual review, suggesting an interest to keep track of the advances made in the study of this group of compounds (Dzubak et al. 2006). Moreover, various biological activities, chemistry and therapeutic potencies of the group have been reviewed to highlight the full potencies of this group of compounds. Among the available reviews are the chemistry and metabolic disease-ameliorative effects (Sheng and Sun, 2011), anti-cancer (Laszczyk, 2009), anti-inflammatory (Safayhi and Sailer, 1997), anti-microbial (Wolska et al. 2010), anti-chagasic (da Silva Ferreira et al. 2013b) and other pharmacological activities (Dzubak et al. 2006). However, a compiled review focusing on the activities of PT against broad range of parasites is lacking. This is despite the potent activities of various members of the group against different parasites as well as the crucial need to develop novel anti-parasitic agents. Hence, a review focusing on the anti-parasitic properties of PT will serve as complementary information in the spectrum of the biological activities of this promising group of phytochemicals.

Available data on plant derived PT investigated for activities against the tropical parasitic infections are reviewed in this paper. This will serve as upto-date information that could provide direction for future scientific research as well as the future application of this group of compounds as anti-parasitic agents. The article could contribute to the search for effective drugs, which is fundamental in the global fight against parasitic infections.

\section{METHODS}

The information presented here is based on PubMed, Medline, SciFinder and Google Scholar search for the PT and their derivatives reported to be tested against parasites of the genera Trypanosoma, Plasmodium, Leishmania, Schistosoma and others, which are considered of importance to tropical countries. Some articles were found through tracking citations in other publications or by accessing the journals' websites. Various keywords were permutated for the search which include: PT, oleanane, friedelane, ursane, taraxasterane, lupane, hopanes, saponins, anti-parasitic, anti-plasmodial, anti-leishmanial, anti-trypanosomal, anti-filarial, nematicidal and schistomicidal. To the best of our knowledge, all the articles that reported a plantderived pentacyclic triterpenoid and nortriterpenoids tested against a parasite were included in this paper. Other articles that reported on synthetic modifications of the plant-derived PT were also included to enable full discussion on the structure-activity relationship. In cases where an article contains the name of a compound only, the structures used in this article were obtained from publication series by Hill and Connolly (2015). On the other hand, the names provided in the articles that used nuclear magnetic resonance spectroscopy (NMR) data in validating the structure of the compounds and synthetic compounds are used. Plant names and families were verified at http://www.theplant list.org database. Overall, the information obtained covered the period; 1985 to the date of submission of this paper.

\section{RESULTS AND DISCUSSION}

A total of 112 naturally occurring PT and saponins isolated from 69 plants belonging to 35 families are reported in this paper. Ten of the total number of the compounds are nortriterpenoids of the quinone methide (possessing friedo-oleanane structure) type isolated mainly from five species of the Celastraceae family. Moreover, 62 of the total number of the compounds are the oleanane (including -friedelanes and -saponins), 19 ursane (-saponins), five taraxastane, 15 lupane (-saponins) and one hopane types of PT. These were isolated mostly from the Araliceae, Rubiaceae, Melastomataceae, Compositae and Lamiaceae plant families. Alongside these naturally occurring PT, 79 synthetic PT were also reported, of which 15 are oleanane types, nine are ursane types, one taraxastane type and 54 are lupane types. The structures of all the compounds are provided in Supplementary Fig. 1 (available from http://journals.cambridge.org/PAR).

The anti-parasitic activities of all the PTs were classified as high, moderate or low/no using the criteria suggested by Pink et al. (2005) and Bero et al. (2011) with modifications. Compounds with high potency (in vitro $\mathrm{IC}_{50} \leqslant 10 \mu \mathrm{g} \mathrm{mL}^{-1}$ against protozoa,), moderate potency (in vitro $\mathrm{IC}_{50} 10-20 \mu \mathrm{g} \mathrm{mL}^{-1}$ against protozoa) and low/no activities $\left(\mathrm{IC}_{50}>20 \mu \mathrm{g} \mathrm{mL}^{-1}\right.$ against protozoa) are summarized in Supplementary 
Tables S1, S2 and S3, respectively (available from http://journals.cambridge.org/PAR). Activity of the compounds against other parasites beside protozoa is classified based on the dosage and activity of the standard drug used in the respective studies. Some compounds were tested in in vivo assays which are also summarized in Table 1.

In order to provide a clear view on the anti-parasitic potential of the PT, logical discussions on the activities of the PT against various parasites are made under separate subheadings. The investigated parasites were found to be different species of Plasmodium, Leishmanium and Trypanosoma, as well as various nematodes and Toxoplasma gondii. Finally, some safety and toxicity profiles of the compounds are briefly discussed.

\section{Brief chemistry of PTs}

As shown in Fig. 1A-E, the PTs of the quinone methides, oleanane and ursane groups generally have five fused six-membered rings (designated ae), while the lupane and hopane types have four six-membered and one five-membered rings. The distinguishing feature between the oleanane and ursane types is the localization of the methyl group on the 'e' ring, whereas the taraxasteranes differ in the orientation of substituents and the positions of double bonds in the backbone. Also, the lupane and the hopane skeletons differ on the localization of the isopropenyl group on the ' $\mathrm{e}$ ' ring. In plants, all these groups of PT (except the nortriterpenoids quinone methides) commonly originate from cyclization of squalene and oxidosqualene via multiple enzymatic and redox stages involving formation of carbocations (Xu et al. 2004; Vincken et al. 2007). Moreover, in the PT possessing the oleanane and ursane backbone, the $\mathrm{C} 4, \mathrm{C} 17$ and $\mathrm{C} 20$ appear to show the highest diversity and unsaturation as well as formation of epoxides, whilst oxygen bridges are formed between the various carbon atoms (Vincken et al. 2007). On the other hand, the $\mathrm{C} 3$ and the substituent at $\mathrm{C} 17$ have been the primary target for synthetic modification. Finally, the saponins of the various PT are formed via attachment of diverse sugar subunits (ranging from 1 to 8 subunits) to the parent skeleton especially at $\mathrm{C} 3$ and $\mathrm{C} 17$ and rarely on $\mathrm{C} 4, \mathrm{C} 16, \mathrm{C} 20, \mathrm{C} 21$ and $\mathrm{C} 22$ (Vincken et al. 2007). Although the physico-chemical properties of saponins as well as the non-glycosylated PT are as diverse as the compounds themselves, the sugar moiety on saponins tend to make them more soluble than the corresponding aglycone (GüçlüÜstündağ and Mazza, 2007).

\section{Anti-plasmodial activities of $\mathrm{P}$ Ts}

Perhaps the most in vitro active anti-plasmodial plant derived PT belong to the small group of quinone methides. Almost all the compounds belonging to the group isolated from different sources were highly active against both chloroquine sensitive and chloroquine resistant strains of Plasmodium falciparum. The compounds are pristimerin (1), isoiguesterol (2), celastrol (3), 28-hydroxyisoiguesterin (4), 17-(methoxycarbonyl)-28-norisoiguesterin (5), 28-nor-isoiguesterin-17-carbaldehyde (6) and Tingenin B (7) which all possessed very low $\mathrm{IC}_{50}$ values $\left(<0 \cdot 5 \mu \mathrm{g} \mathrm{mL}^{-1}\right)$ against $P$. falciparum (Supplementary Table S1, available from http://journals.cambridge.org/PAR) (Figueiredo et al. 1998; Maregesi et al. 2010; Ruphin et al. 2013).

The oleanane PT also showed high to low activity against Plasmodia. Epi-Oleanolic acid (OA) (11) from Viola verecunda inhibited the growth of the chloroquine sensitive D10 strain of P. falciparum with a very low $\mathrm{IC}_{50}$ of $0 \cdot 018 \mu \mathrm{g} \mathrm{mL}^{-1}$ which was close to that of artemisinin $\left(0.015 \mu \mathrm{g} \mathrm{mL}^{-1}\right)$ (Moon et al. 2007). However, the same compound isolated from Celaenodendron mexicanum had moderate activity against multidrug resistant $\mathrm{K} 1$ strain of the parasite $\left(\mathrm{IC}_{50} 12.92 \mu \mathrm{g} \mathrm{mL}^{-1}\right.$ ) (Camacho et al. 2000). Another oleanane $\mathrm{PT}$ with potent anti-P. falciparum activities is $1-\mathrm{O}-[\alpha-\mathrm{L}-($ rhamnopyranosyl $)]-23$-acetoimberbic acid 29-methyl ester (12) from Pittosporum mannii $\left(\mathrm{IC}_{50} 1 \cdot 2 \mu \mathrm{g} \mathrm{mL}^{-1}\right.$ ) (Nyongbela et al. 2013). Furthermore, OA (13) isolated from different plant species has been shown to possess anti-plasmodial activities with $\mathrm{IC}_{50}$ ranging from $2 \cdot 1 \mu \mathrm{g} \mathrm{mL}^{-1}$ against chloroquine sensitive clone D6 (He et al. 2005) to $88 \mu \mathrm{g} \mathrm{mL}^{-1}$ against multidrug resistant K1 strain of P.falciparum (Steele et al. 1999). Large variation in $\mathrm{IC}_{50}$ values for the same compound often reflects the differences in the parasite strain or sometimes different experimental procedures. Moreover, the variations in the documented anti-plasmodial activities of OA might suggest that strain differences are critical for the anti-plasmodial effects of the oleananes.

Another moderately active anti-plasmodial oleanane PT and the most extensively investigated is maslinic acid (MA) (61). Incubation of different concentrations of the compound obtained from the fruits of Olea europaea with $P$. falciparum (at different growth stages) showed that the compound arrests the maturation of the intraerythrocytic parasites from early-ring to schizont stages. The $\mathrm{IC}_{50}$ for the chloroquine sensitive and chloroquine resistant strains of the parasite were $15 \cdot 13$ and $12 \cdot 29 \mu \mathrm{g}$ $\mathrm{mL}^{-1}$, respectively (Moneriz et al. 2011a). The proposed mechanism of the anti-plasmodial activity of oleanane-type PT is via incorporation into the erythrocytes membrane thereby modifying accessibility of the parasites into the cells (Sairafianpour et al. 2003). Indeed, other studies have demonstrated that PT exert their anti-parasitic activities via an interaction with the host cell membranes (Ziegler et al. 2006; Broniatowski et al. 2012). 
Table 1. In vivo antiparasitic activities of pentacyclic triterpenes

\begin{tabular}{|c|c|c|c|c|c|}
\hline Class & Compound & Plant & Parasites/dosage used & Activity & Reference \\
\hline \multirow[t]{10}{*}{$\begin{array}{l}\text { Oleanane; } \\
\text { Quinone } \\
\text { methide }\end{array}$} & $(5)$ & $\begin{array}{l}\text { Salacia kraussii } \\
\text { (Harv.) Harv. } \\
\text { (Celastraceae) }\end{array}$ & $\begin{array}{l}\text { P. berghei }(10 \mathrm{mg} \\
\left.\mathrm{kg}^{-1} \text { bw }\right)\end{array}$ & Inactive & $\begin{array}{l}\text { Figueiredo et al. } \\
\text { (1998) }\end{array}$ \\
\hline & $(23-28)$ & $\begin{array}{l}\text { Maesa balansae Mez } \\
\text { (Myrsinaceae) }\end{array}$ & $\begin{array}{l}\text { L. infantum: amasti- } \\
\text { gotes }(0 \cdot 2-0 \cdot 4 \mathrm{mg} \\
\left.\mathrm{kg}^{-1} \mathrm{bw}\right)\end{array}$ & $\begin{array}{l}>90 \% \text { parasite reduction } \\
\text { after } 1 \text {-week treatment }\end{array}$ & $\begin{array}{l}\text { Germonprez } \\
\text { et al. }(2005)\end{array}$ \\
\hline & $(25)$ & $\begin{array}{l}\text { Maesa balansae Mez } \\
\text { (Myrsinaceae) }\end{array}$ & $\begin{array}{l}\text { L. donovani amasti- } \\
\text { gotes: }(0 \cdot 2-0 \cdot 8 \mathrm{mg} \\
\left.\mathrm{kg}^{-1} \mathrm{bw}\right)\end{array}$ & $\begin{array}{c}>90 \% \text { parasite reduction } \\
\text { after } 1 \text {-week treatment }\end{array}$ & $\begin{array}{l}\text { Maes et al. } \\
\text { (2004) }\end{array}$ \\
\hline & $(61)$ & - & $\begin{array}{l}\text { P. yoelii }\left(40 \mathrm{mg} \mathrm{kg}^{-1}\right. \\
\text { bw) }\end{array}$ & $\begin{array}{l}>80 \% \text { survival rate after } \\
1 \text {-week treatment }\end{array}$ & $\begin{array}{l}\text { Moneriz et al. } \\
(2011 b)\end{array}$ \\
\hline & \multirow[t]{3}{*}{ (13) } & $\begin{array}{l}\text { Miconia fallax DC } \\
\text { (Melastomataceae) }\end{array}$ & $\begin{array}{l}\text { T. cruzi }\left(50 \mathrm{mg} \mathrm{kg}^{-1}\right. \\
\left.\text { day }^{-1}\right)\end{array}$ & $\begin{array}{l}76 \% \text { parasite reduction } \\
\text { after } 1 \text {-week treatment }\end{array}$ & $\begin{array}{l}\text { da Silva Ferreira } \\
\text { et al. }(2013 a)\end{array}$ \\
\hline & & - & $\begin{array}{l}\text { T. cruzi }\left(20 \mathrm{mg} \mathrm{kg}^{-1}\right. \\
\left.\text { day }^{-1} \text { oral }\right)\end{array}$ & $\begin{array}{l}40 \% \text { parasite reduction } \\
\text { after } 3 \text {-week treatment }\end{array}$ & $\begin{array}{l}\text { da Silva Ferreira } \\
\text { et al. }(2010)\end{array}$ \\
\hline & & $\begin{array}{l}\text { Lantana camara } \\
\text { L. (Verbenaceae) }\end{array}$ & $\begin{array}{l}\text { B. malayi }(200 \mathrm{mg} \\
\mathrm{kg}^{-1} \mathrm{bw} \mathrm{oral} \mathrm{and} \\
100 \mathrm{mg} \mathrm{kg}^{-1} \mathrm{bw} \\
\text { intraperitoneal })\end{array}$ & $\begin{array}{l}\text { Inactive against microfi- } \\
\text { lariid; } 18 \cdot 18 \% \text { macrofi- } \\
\text { lacidal activity } \\
\text { compared to untreated } \\
\text { control for } 5 \text { days }\end{array}$ & $\begin{array}{l}\text { Misra et al. } \\
\text { (2007) }\end{array}$ \\
\hline & $(66)$ & $\begin{array}{l}\text { Lantana camara } \\
\text { L. (Verbenaceae) }\end{array}$ & $\begin{array}{l}\text { B. malayi }(200 \mathrm{mg} \\
\mathrm{kg}^{-1} \mathrm{bw} \text { oral and } \\
100 \mathrm{mg} \mathrm{kg}^{-1} \mathrm{bw} \\
\text { intraperitoneal })\end{array}$ & $\begin{array}{l}\text { Inactive against microfi- } \\
\text { lariid and macrofilariid } \\
\text { after } 5 \text { days treatment }\end{array}$ & $\begin{array}{l}\text { Misra et al. } \\
\quad(2007)\end{array}$ \\
\hline & (33) & - & $\begin{array}{l}\text { L. donovani promas- } \\
\text { tigotes }\left(50 \mathrm{mg} \mathrm{kg}^{-1}\right. \\
\text { bw day }{ }^{-1} 3 \text { times } 5 \\
\text { day apart) }\end{array}$ & $\begin{array}{c}100 \% \text { parasite clearance } \\
\text { by the end of } 45 \text { days }\end{array}$ & Ukil et al. (2005) \\
\hline & $(36,37)$ & - & $\begin{array}{l}\text { B. malayi }(100 \mathrm{mg} \\
\left.\mathrm{kg}^{-1}\right)\end{array}$ & $\begin{array}{l}54 \% \text { parasite death after } \\
5 \text { days treatment }\end{array}$ & $\begin{array}{l}\text { Kalani et al. } \\
\text { (2013) }\end{array}$ \\
\hline \multirow[t]{5}{*}{ Ursane } & $(89)$ & $\begin{array}{l}\text { Mimusops caffra E. } \\
\text { Mey. ex A.DC } \\
\text { (Sapotaceae) }\end{array}$ & P. berghei & $\begin{array}{l}94 \cdot 01 \% \text { parasite reduc- } \\
\text { tion after } 4 \text {-day } \\
\text { treatment }\end{array}$ & $\begin{array}{l}\text { Simelane et al. } \\
\text { (2013) }\end{array}$ \\
\hline & \multirow[t]{3}{*}{$(88)$} & - & 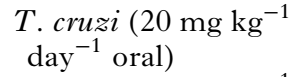 & $\begin{array}{l}60 \% \text { parasite reduction } \\
\text { after } 3 \text {-week treatment }\end{array}$ & $\begin{array}{l}\text { da Silva Ferreira } \\
\text { et al. }(2010)\end{array}$ \\
\hline & & $\begin{array}{l}\text { Miconia fallax DC } \\
\text { (Melastomataceae) }\end{array}$ & $\begin{array}{l}\text { T. } \text { cruzi }\left(50 \mathrm{mg} \mathrm{kg}^{-1}\right. \\
\left.\text { day }^{-1}\right)\end{array}$ & $\begin{array}{l}79 \% \text { parasite reduction } \\
\text { after } 1 \text {-week treatment }\end{array}$ & $\begin{array}{c}\text { da Silva Ferreira } \\
\text { et al. }(2013 a)\end{array}$ \\
\hline & & $\begin{array}{l}\text { Miconia sellowiana } \\
\text { Naud. } \\
\text { (Melastomataceae) }\end{array}$ & $\begin{array}{l}\text { T. cruzi }\left(2 \mathrm{mg} \mathrm{kg}^{-1}\right. \\
\text { bw day }\end{array}$ & $\begin{array}{l}75 \cdot 7 \% \text { parasite reduction } \\
\text { after } 1 \text {-week treatment }\end{array}$ & $\begin{array}{l}\text { Cunha et al. } \\
\text { (2006) }\end{array}$ \\
\hline & (93) & - & 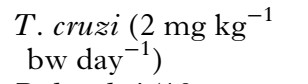 & $\begin{array}{c}70 \cdot 4 \% \text { parasite reduction } \\
\text { after } 1 \text {-week treatment }\end{array}$ & $\begin{array}{l}\text { Cunha et al. } \\
(2006)\end{array}$ \\
\hline Taraxastane & $(115)$ & $\begin{array}{r}\text { Pluchea lanceolata } \\
\text { DC. (Asteraceae) }\end{array}$ & $\begin{array}{l}\text { P. berghei }(10 \mathrm{mg} \\
\left.\mathrm{kg}^{-1} \mathrm{bw}\right)\end{array}$ & $\begin{array}{l}51 \cdot 20 \% \text { suppression of } \\
\text { parasitaemia after } 1- \\
\text { week treatment }\end{array}$ & $\begin{array}{l}\text { Mohanty et al. } \\
\text { (2013) }\end{array}$ \\
\hline \multirow[t]{4}{*}{ Lupane } & $(140)$ & $\begin{array}{l}\text { Bacopa monniera } \\
\text { Hayata \& Matsum. } \\
\text { (Plantaginaceae) }\end{array}$ & $\begin{array}{l}\text { L. donovani }(10 \mathrm{mg} \\
\left.\mathrm{kg}^{-1} \mathrm{bw}\right)\end{array}$ & $\begin{array}{l}92 \% \text { parasite reduction } \\
\text { after } 6 \text {-week treatment }\end{array}$ & $\begin{array}{l}\text { Chowdhury } \\
\text { et al. (2003) }\end{array}$ \\
\hline & $(130)$ & - & $\begin{array}{l}\text { P. berghei }(100 \mathrm{mg} \\
\left.\mathrm{kg}^{-1} \mathrm{bw}\right)\end{array}$ & $\begin{array}{l}70 \% \text { parasite reduction } \\
\text { after } 7 \text { days treatment }\end{array}$ & $\begin{array}{l}\text { De Sá et al. } \\
(2009)\end{array}$ \\
\hline & (129) & $\begin{array}{l}\text { Uapaca nitida Müll- } \\
\text { Arg. } \\
\text { (Euphorbiaceæ) }\end{array}$ & $\begin{array}{l}\text { P. berghei }(0-250 \mathrm{mg} \\
\left.\mathrm{kg}^{-1} \mathrm{day}^{-1}\right)\end{array}$ & Inactive & $\begin{array}{l}\text { Steele et al. } \\
\text { (1999) }\end{array}$ \\
\hline & $(128)$ & Vernonia Brasiliana & $\begin{array}{l}\text { P. berghei }(15 \mathrm{mg} \\
\left.\mathrm{kg}^{-1} \mathrm{bw}\right)\end{array}$ & Inactive & $\begin{array}{l}\text { Alves et al. } \\
\text { (1997) }\end{array}$ \\
\hline
\end{tabular}

On the other hand, some oleanane PT such as $\beta$ amyrin (19), arjun glucoside (73), sericoside (74), and maytensifolin B (22) were shown to possess very low or no anti-plasmodial activity (Supplementary Table S3, available from http:// journals.cambridge.org/PAR). However, it is also noteworthy that these low active anti-plasmodial oleanane PT totally lack an acid group and/or the
C3 hydroxyl or these groups are derivatized/ sterically hindered (Cunha et al. 2003). This signifies the role of the polar groups at C27 and C3 in the anti-plasmodial activity of this class of PT.

In the ursane group, ursolic acid (UA) (88) isolated from Baccharis dracunculifolia had the highest reported in vitro activity against chloroquine sensitive $P$. falciparum with $\mathrm{IC}_{50}$ of $1 \mu \mathrm{g} \mathrm{mL}^{-1}$ (da Silva Filho 

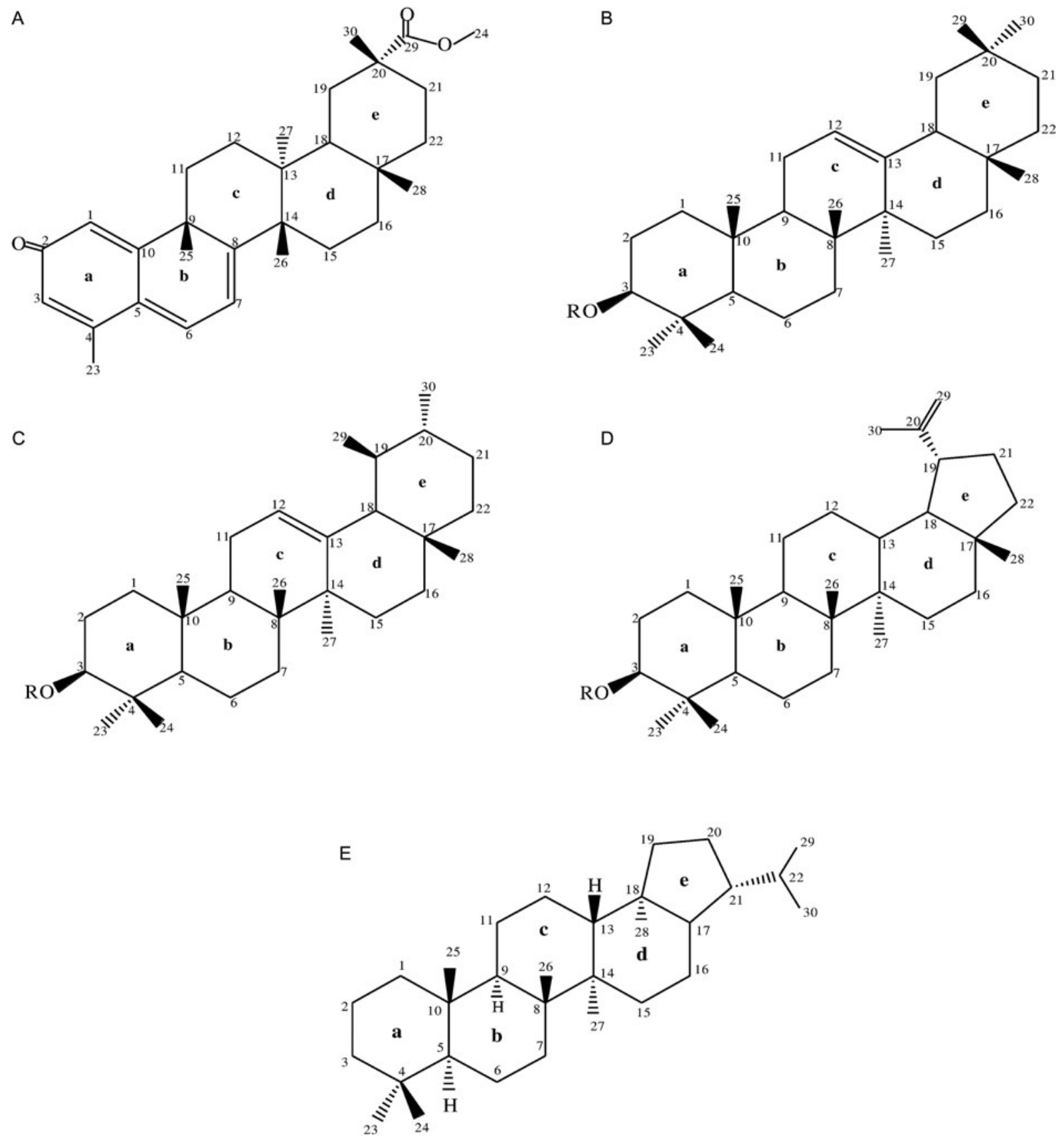

Fig. 1. Representative skeletons of the different classes of pentacyclic triterpenes showing the carbon numbers and ring annotations. (A) Quinone methides, (B) oleananes, (C) ursanes, (D) lupanes, and (E) taraxastanes.

et al. 2009). Additionally, UA from the leaves of Mimusops caffra showed an $\mathrm{IC}_{50}$ of $6.8 \mu \mathrm{g} \mathrm{mL}-1$ against chloroquine sensitive D10 strain of $P$. falciparum (Simelane et al. 2013). The activity was boosted by derivatization of the compound to $3 \beta-\mathrm{O}-$ acetylursolic acid (89) and 3-oxo-ursolic acid (99) with $\mathrm{IC}_{50}$ of 1.9 and $7.3 \mu \mathrm{g} \mathrm{mL}^{-1}$ respectively, using the same organism. However, other reports on the anti-plasmodial activity of UA contradict the above findings. For instance, Suksamrarn et al. (2003) and Graziose et al. (2012) reported UA to be inactive against multidrug resistant and chloroquine sensitive strains of $P$. falciparum respectively. It is pertinent to note that the authors used either different methods or compound dilutions in the anti-plasmodial assay protocol which highlights the need for harmonization of protocols from different laboratories for easier comparison. Other ursanes with potent anti-plasmodial activity are uvaol (92) and $2 \alpha$-hydroxy-ursolic acid (90) isolated from Baccharis dracunculifolia with $\mathrm{IC}_{50}$ of 1.9 and $3 \mu \mathrm{g} \mathrm{mL}{ }^{-1}$ respectively against a chloroquine resistant $\mathrm{K} 1$ strain as well as 3 -acetylpomolic acid (101) $\left(\mathrm{IC}_{50} 2 \cdot 1 \mu \mathrm{g}\right.$ $\left.\mathrm{mL}^{-1}\right)$ and pomolic acid (100) $\left(\mathrm{IC}_{50} 3.47 \mu \mathrm{g} \mathrm{mL}^{-1}\right)$ both isolated from Markhamia tomentosa (da Silva Filho et al. 2009; Tantangmo et al. 2010). Hence, ursane-type PT also provide a promising class of anti-plasmodials for future research. 
The lupane-type PT investigated for anti-plasmodial activity include betulinic acid (BA) (129) isolated from Harungana madagascariensis and Zizyphus vulgaris with $\mathrm{IC}_{50}$ values of $2 \cdot 33$ and $6 \cdot 3 \mu \mathrm{g} \mathrm{mL} \mathrm{mL}^{-1}$ against $\mathrm{W} 2$ and $3 \mathrm{D} 7$ strains of $P$. falciparum respectively (Lenta et al. 2007; de Sá et al. 2009). A structural analogue of BA isolated from Diospyros quaesita highlights the importance of derivatization of the compound at $\mathrm{C} 3$ (true also for OA and UA) for potentiation of anti-plasmodial activity. The 3caffeate derivative of BA (122) isolated from the plant was active against both chloroquine sensitive D6 and chloroquine resistant W2 strains of $P$. falciparum with $\mathrm{IC}_{50}$ of 0.86 and $0.61 \mu \mathrm{g} \mathrm{mL} \mathrm{m}^{-1}$ respectively. This activity was enhanced with double acetylation of the caffeate (121) $\left(\mathrm{IC}_{50} 0.45\right.$ and $0.42 \mu \mathrm{g} \mathrm{mL}^{-1}$, respectively) (Ma et al. 2008). Similar results were obtained with other derivatives such as messagenic acid $\mathrm{A}(\mathbf{1 2 3})$ and messagenic acid $\mathrm{B}$ (124) (trans and cis $\mathrm{C} 27$ coumaroyl derivatives of BA, respectively) isolated from Gardenia saxatalis which possessed $\mathrm{IC}_{50}$ of 1.5 and $3.8 \mu \mathrm{g} \mathrm{mL}^{-1}$ respectively against a multidrug resistant strain of $P$. falciparum while the non-derivatized BA (also OA and UA) was inactive (Suksamrarn et al. 2003). Moreover, cis and trans C3 coumaroyl derivatives of BA (138 and 139) isolated from Cornus florida were also highly active derivatives against $P$. falciparum $\mathrm{D} 10$ with $\mathrm{IC}_{50}$ of $6 \cdot 03$ and $9 \cdot 22 \mu \mathrm{g} \mathrm{mL} \mathrm{m}^{-1}$ respectively (Graziose et al. 2012). Other naturally occurring lupane-type P'T active against the K1 strain of $P$. falciparum are betulone (126) and lupenone (127) with $\mathrm{IC}_{50}$ of 1.32 and $2 \mu \mathrm{g} \mathrm{mL}^{-1}$, respectively (Gachet et al. 2011). However, synthetic modifications of BA did not lead to profound increase in activity. Ziegler et al. (2004) reported the activities of methyl betulinate (125), betulinic aldehyde (131), betulinic acid amide (132), lupeol (128) and betulin (134) which were $\mathrm{IC}_{50}$ of $3 \cdot 3,6 \cdot 2,6 \cdot 4$, $11 \cdot 8$, and $<12 \mu \mathrm{g} \mathrm{mL}^{-1}$ respectively against $P$. falciparum. The more interesting finding of the study, however, was that BA, 131 and 134 resulted in a dose-dependent structural change in the membrane of non-parasitized erythrocytes. The compounds consequently prevented entry of $P$. falciparum merozoites into non-parasitized erythrocytes. These findings demonstrated that lupane-type PT may also restrict parasites' erythrocyte invasion in vitro via a mechanism that involves modulation of the erythrocytic membrane.

Few PT were investigated for possible in vivo antiplasmodial activity based on their promising in vitro activities. The only oleanane-type PT that was investigated for in vivo anti-plasmodial activity was MA (61). Mice were infected with the lethal strain of Plasmodium yoelii and treated with a daily single intraperitoneal dose of $40 \mathrm{mg} \mathrm{kg}^{-1}$ body weight (bw) MA. As found in the in vitro studies, MA demonstrated a static effect on the parasite with accumulated schizonts in the erythrocytes of the infected mice. However, the treated mice consistently maintained lower levels of parasitaemia and remained immunoprotected against further infection with the parasite after 40 days (Moneriz et al. $2011 b$ ). Further analysis of the possible mechanism of action of MA suggested a multi routed mechanism involving the inhibition of a number of proteases necessary for the growth of the parasite. Other binding sites for MA, which include the Plasmodium phospholipase, were putatively proposed in an in silico analysis (Moneriz et al. 2011c). This remarkable in vivo activity demonstrated by MA calls for similar investigation on other oleanane-type PT especially those with even lower in vitro $\mathrm{IC}_{50}$ than MA such as epi-OA (11).

On the other hand, 3 $\beta$-O-acetylursolic acid (89) was shown to suppress $94 \cdot 01 \%$ of circulating Plasmodium berghei in mice (effective concentration not clear in the report). The compound was also less cytotoxic against HEK293 and HepG2 cell lines (Simelane et al. 2013). Furthermore, taraxasterol acetate (115) isolated from Pluchea lanceolata at $10 \mathrm{mg} \mathrm{kg}^{-1}$ bw suppressed $52 \cdot 20 \%$ of circulating $P$. berghei in mice and showed 7 days extension of mean survival time (Mohanty et al. 2013). In another study, in vivo evaluation of betulinic acid revealed that the compound was ineffective in reducing $P$. berghei in mice even at $250 \mathrm{mg} \mathrm{kg}^{-1} \mathrm{bw} \mathrm{day}^{-1}$ (Steele et al. 1999).

One of the greatest limitation on the in vivo activity of PT, especially the less polar among them, is the hydrophobicity. Moreover, another limitation is the high cytotoxicity of some classes. For instance, Pristimerin (1) isolated from Salacia leptoclada was shown to have a selective index of $<1$ for P338 leukaemia cell lines (Ruphin et al. 2013), whereas 17(methoxycarbonyl)-28-nor-isoiguesterin (5) at 10 $\mathrm{mg} \mathrm{kg}^{-1}$ bw was toxic to mice after just one day of administration (Figueiredo et al. 1998). The latter compound which was isolated from $S$. kraussii although being the most active of all PT against chloroquine-resistant $P$. falciparum in vitro $\left(\mathrm{IC}_{50}\right.$ $\left.0.037 \mu \mathrm{g} \mathrm{mL}^{-1}\right)$, was unable to clear $P$. berghei in mice treated with 1 and $5 \mathrm{mg} \mathrm{kg}^{-1}$ bw (Figueiredo et al. 1998). Therefore, bioavailability and cytotoxicity should be taken into account when further developing P'T as possible anti-plasmodial agents is considered especially if the oral route is to be used. Moreover, these compounds could at least serve as structural backbones for synthesis of less toxic and more efficient compounds.

\section{Anti-trypanosomal activities of PTs}

Tingenin B ( 7$)$, a quinone methide, is the most active reported PT against Trypanosoma brucei brucei and Trypanosoma cruzi with $\mathrm{IC}_{50}<0.25 \mu \mathrm{g} \mathrm{mL} \mathrm{m}^{-1}$ against each of the species. However, as observed 
with other compounds belonging to the same class, the compound was highly cytotoxic on MCR-5 cells $\left(\mathrm{IC}_{50} \quad 0.45 \mu \mathrm{g} \mathrm{mL}^{-1}\right.$ ) (Maregesi et al. 2010). On the other hand, UA $(\mathbf{8 8})$ has been reported in many studies to possess anti-trypanosomal activity with low $\mathrm{IC}_{50}$. The compound isolated from Strachynos spynosa possessed an $\mathrm{IC}_{50}$ of $1 \mu \mathrm{g} \mathrm{mL}-1$ against T. brucei brucei (Hoet et al. 2007). Furthermore, in a study by Abe et al. (2002), UA from Rosmanirus officinalis with an $\mathrm{MC}_{100}$ of $40 \mu \mathrm{g}$ $\mathrm{mL}^{-1}$ was shown to be $86 \%$ more effective than the natural trypanocidal compound gossypol (Abe et al. 2002). Other structural analogues of UA were less effective or inactive against trypanosomes. The carboxylic group at $\mathrm{C} 17$ appears to be important for the anti-trypanosomal action of UA as evident in lower activities of uvaol (92) (aldehyde group replacing carboxyl) with an $\mathrm{IC}_{50}$ of $12.3 \mu \mathrm{g} \mathrm{mL}^{-1}$ and $\alpha$-amyrin (95) (methyl group replacing carboxyl) with $\mathrm{IC}_{50}$ of $48 \mu \mathrm{g} \mathrm{mL} \mathrm{mL}^{-1}$. Likewise, $\beta$-amyrin (19) $\left(\mathrm{IC}_{50} 54 \cdot 2 \mu \mathrm{g} \mathrm{mL}\right)$ with $\mathrm{CH}_{3}$ in place of $\mathrm{COOH}$ at $\mathrm{C} 17$ of $\mathrm{OA}\left(\mathrm{IC}_{50} 2 \cdot 9 \mu \mathrm{g} \mathrm{mL}^{-1}\right)$ lost anti-trypanosomal activity against $T$. brucei brucei (Hoet et al. 2007). The $\mathrm{OH}$ at $\mathrm{C} 3$ also appears to be equally important in the trypanosomal action of both UA and OA (Cunha et al. 2003; Taketa et al. 2004). This is confirmed by the loss in the activity against $T$. cruzi of UA in a mixture with OA with addition of acetyl group at C3 (14 and 89, respectively) of both compounds (Cunha et al. 2003). Moreover, oleanonic acid (66) and 3,11-dioxoolean-12-en-28-onic acid (67) ( IC $_{50} 113.62$ and $173.9 \mu \mathrm{g} \mathrm{mL}^{-1}$ against T. cruzi, respectively) which are similar in structure with OA but with adulterated $\mathrm{C} 3$ possessed no activity against the parasite (Cunha et al. 2003; Hoet et al. 2007; Leite et al. 2008). However, replacement of the $\mathrm{C} 3 \mathrm{OH}$ of OA with a polar group in saponin (18) did not lead to a loss in activity (Taketa et al. 2004). From these findings, it is evident that the presence (and/or property) of the C3 hydroxyl group and $\mathrm{C} 17 \mathrm{COOH}$ group are significant for the trypanocidal activity of the ursane and oleanane-type PT. The role of $\mathrm{C} 3 \mathrm{OH}$ may be, in part, to increase the polarity of the compound because glycosylation of the group in OA with a disaccharide (3-O- $[\beta-\mathrm{D}$-glucopyranosyl-(1-2)- $\beta$-D-galactopyranosyl]) (18) or addition of potassium in UA (93) were found to maintain the activity against $T$. brucei brucei $\left(\mathrm{IC}_{50}\right.$ $\left.3 \cdot 05 \mu \mathrm{g} \mathrm{mL}^{-1}\right)$ and $T$. cruzi $\left(\mathrm{IC}_{50} 4 \cdot 26 \mu \mathrm{g} \mathrm{mL}^{-1}\right)$, respectively (Taketa et al. 2004; Cunha et al. 2006). However, substitution of the neighbouring carbon (C4) to C3 appears to counteract the effect despite the presence of additional polar groups as seen in the loss of activity of both brevicuspisaponin 1 and 2 (102 and 103) against T. brucei brucei where UA was most potent (Taketa et al. 2004). This suggests that in addition to increasing the polarity of the compounds, the nature and orientation of substituents at positions C3 and C17 may be involved directly in the activities of PT. Furthermore, the double bond between $\mathrm{C} 12$ and $\mathrm{C} 13$ may also play a role in the activity because friedelanol (85) lacking any double bond was inactive despite the presence of a $\mathrm{C} 3 \mathrm{OH}$ (da Silva Filho et al. 2004).

The anti-trypanosomal activity of the lupane group appeared in very few reports. Hoet et al. (2007) reported anti-T. brucei brucei activity of betulin (134), betulinic acid (129) and lupeol (128) with $\mathrm{IC}_{50}$ values of $4 \cdot 0,14 \cdot 9$ and $19 \cdot 3 \mu \mathrm{g} \mathrm{mL}{ }^{-1}$, respectively.

In an in vivo setup, UA, OA and the potassium salt of UA (93) were potent against the lethal Y strain of T. cruzi in mice treated with daily intraperitoneal dose of $2 \mathrm{mg} \mathrm{kg}^{-1} \mathrm{bw}$. The treatment led to a reduction of parasite load in the infected rats more markedly by UA and the salt $(75 \cdot 7$ and $70 \cdot 4 \%$, respectively) (Supplementary Table S1, available from http://journals.cambridge.org/PAR) (Cunha et al. 2006). In another study, da Silva Ferreira et al. (2010) reported 60 and 40\% reduction in Bolivia strain of T. cruzi after treatment of infected rats with $\mathrm{UA}$ and $\mathrm{OA}$ at doses of $20 \mathrm{mg} \mathrm{kg}^{-1} \mathrm{bw}$ day $^{-1}$ orally. Findings of a later study demonstrated that the effectiveness of UA and OA treatment in $T$. cruzi infected mice is dependent on the bioavailability of the compound. It was observed that oral administration of the compounds $\left(50 \mathrm{mg} \mathrm{kg}^{-1} \mathrm{bw}\right.$ day $^{-1}$ ) resulted in 79 and $76 \%$ decrease in parasitaemia respectively, while administration of the same concentration via the intraperitoneal route was not effective. Presumably, the intraperitoneal route achieved higher effective concentration of the compounds, which could have modulatory effects on pro and anti-inflammatory cytokines that resulted in an observed immunosuppression (da Silva Ferreira et al. 2013a). These effects may hence essentially counter the destructive effects of the compounds on the parasites since the immune system at some point of $T$. cruzi infection participate in parasite clearance (Tarleton, 2007). Hence, at low concentrations (which is achieved via the oral route due to low oral bioavailability of UA and OA or low intraperitoneal dose), the compounds are sufficient to destroy the parasites on their capacity or via other mechanisms.

On a final note, the anti-trypanosomal potential of PT is equally promising. Further research in this area should be directed towards screening more PT (especially the quinone methides) against various species of Trypanosoma. The need to investigate the compounds in animal models is also paramount because the compounds appear to facilitate parasite clearance via stimulation of host mechanisms which cannot be attained in vitro. In this regard, alternating the routes of administration is critical in order to provide a conclusive profile on the full potencies of $\mathrm{PT}$ as anti-trypanosomal agents. 


\section{Anti-leishmanial activities of PTs}

A number of studies have been conducted on the activity of PT against promastigotes and amastigotes of various Leishmania species. A range of saponin glycosides belonging to the oleanane PT isolated from Maesa balansae were very active against Leishmania infantum amastigotes with very low $\mathrm{IC}_{50}$. The most active among them designated maesabalide III (25) possessed an $\mathrm{IC}_{50}$ of $0.007 \mu \mathrm{g}$ $\mathrm{mL}^{-1}$. Other maesabalides $(23,24,26,27$ and 28$)$ gave $\mathrm{IC}_{50}$ values of $0 \cdot 014-0 \cdot 046 \mu \mathrm{g} \mathrm{mL}^{-1}$ (Germonprez et al. 2005). Oleonolic acid (13) isolated from Salvia cilicica also possessed activity with $\mathrm{IC}_{50}$ of 0.04 and $0.029 \mu \mathrm{g} \mathrm{mL}^{-1}$ against promastigotes and amastigote of Leishmania donovani, respectively (Tan et al. 2002). Here also, the $\mathrm{C} 3 \mathrm{OH}$ of OA appears to play a crucial role in the activity as a conformational change tends to decrease the antileishmanial activity of the compound. This is because the activity of epi-OA (11) isolated from Celaendendron maxicanum was hundred-fold lower against the same parasite $\left(\mathrm{IC}_{50} 8.59 \mu \mathrm{g} \mathrm{mL}^{-1}\right)$ (Camacho et al. 2000). However, acetylation of the $\mathrm{C} 3 \mathrm{OH}$ group of OA may not cause a greater loss in activity. This is evident with acetylation of OA to form 3-OA acetate (14) which possessed an $\mathrm{IC}_{50}$ $2.49 \mu \mathrm{g} \mathrm{mL}^{-1}$ against Leishmania amazonensis (Gnoatto et al. 2008). Other oleanane triterpenes with potent activities include hederacolchiside $\mathrm{A}_{1}$ (32) $\left(\mathrm{IC}_{50} 0.061 \mu \mathrm{g} \mathrm{mL}{ }^{-1}\right), \beta$-hederin (16) $\left(\mathrm{IC}_{50}\right.$ $\left.0.26 \mu \mathrm{g} \mathrm{mL}^{-1}\right)$ and $\alpha$-hederin (15) ( $\left.\operatorname{IC}_{50} 0 \cdot 3 \mu \mathrm{g} \mathrm{mL}\right)$ from two hedera species against amastigotes of Leishmania mexicana (Ridoux et al. 2001; Tantangmo et al. 2010). On the other hand, glycyrrhitinic acid (GRA) (33), a derivative of $\beta$-amyrin (19) was also potent against $L$. donovani promastigotes in vitro with an $\mathrm{IC}_{50}$ of $4.6 \mu \mathrm{g} \mathrm{mL}^{-1}$ (Ukil et al. 2005).

Among the ursanes, UA (88) isolated from Salvia cilicica appears to be the most active against both promastigotes and amastigotes forms of $L$. donovani and Leishmania major with low $\mathrm{IC}_{50}$ values of 0.0032 $0.042 \mu \mathrm{g} \mathrm{mL}^{-1}$ (Tan et al. 2002). However, other studies with UA reported much higher $\mathrm{IC}_{50}$ of 2.28 $\mu \mathrm{g} \mathrm{mL}^{-1}$ against L. amazonensis (Torres-Santos et al. 2004), $3 \cdot 7 \mu \mathrm{g} \mathrm{mL}^{-1}$ against $L$. donovani (da Silva Filho et al. 2009) and $4.55 \mu \mathrm{g} \mathrm{mL}^{-1}$ against Leishmania tarentolae (Graziose et al. 2012). Some structural modification of UA led to reduction in activity as reported for $2 \alpha$-hydroxy-ursolic acid (90) and uvaol (92) $\left(\mathrm{IC}_{50} 19\right.$ and $15 \mu \mathrm{g} \mathrm{mL}^{-1}$ respectively against L. donovani) (da Silva Filho et al. 2009). On the other hand, a bis-(3-aminopropyl) piperazine moiety added to the carboxylic acid of $3 \beta$-acetylursolic acid (89) in compounds $\mathbf{1 0 6}-\mathbf{1 0 8}$ retained the activity of UA against promastigotes of Leishmania infantum and L. amazonensis ( $\mathrm{IC}_{50} 6-17 \mu \mathrm{g} \mathrm{mL}^{-1}$ ) (Gnoatto et al. 2008). From the above findings, UA appears to be a potent anti-leishmanial agent against multiple species of the parasites. Because the investigated structural modification did not lead to an increase in activity, further modifications of the parent UA may be an experimental strategy for further development of ursane-type PT as anti-leishmanial agents. Other ursane-type $\mathrm{PT}$ with promising in vitro anti-leishmanial activity include pomolic acid (100) and 3-acetyl pomolic acid (101) from Markhamia tomentosa $\left(\mathrm{IC}_{50}\right.$ $0.31 \mu \mathrm{g} \mathrm{mL}^{-1}$ and $3.4 \mu \mathrm{g} \mathrm{mL}^{-1}$, respectively) against L. donovani and synthetic $\mathrm{N}$-\{3-[4-(3-Aminopropyl) piperazinyl]propyl\}-3-O-acetylursolamide (IC I $_{50} 3.7 \mu \mathrm{g} \mathrm{mL}^{-1}$ against L. infantum) (Gnoatto et al. 2008; Tantangmo et al. 2010).

In the lupane group, a few derivatives of BA were active against Leishmania although the parent compound was inactive in multiple studies. Betulinic acid acetate (130) and trans and cis 3-coumarol derivatives of $\mathrm{BA}$ (138 and 139) isolated from Cornus florida had $\mathrm{IC}_{50}$ values of $0 \cdot 45,5 \cdot 14$ and $1.36 \mu \mathrm{g}$ $\mathrm{mL}^{-1}$ respectively against $L$. tarentolae (Graziose et al. 2012). Moreover, dihydrobetulinic acid (DHBA) (143) from Bacopa monniera possessed an $\mathrm{IC}_{50}$ of $2 \cdot 6$ and $4 \cdot 1 \mu \mathrm{g} \mathrm{mL}^{-1}$ against $L$. amazonensis promastigotes and amastigotes, respectively (Chowdhury et al. 2003). Although a number of structural modification of the lupane-type PT led to loss in anti-leishmanial activity (Supplementary Table S3, available from http://journals.cambridge. org/PAR), future research on the group may be targeted towards different synthetic classes of the compounds and species of the parasite.

In an in vivo study, the anti-leishmanial activity of GRA (33) was further assessed where rats were treated with $50 \mathrm{mg} \mathrm{kg}^{-1} \mathrm{bw} \mathrm{day}^{-1}$ (given three times, 5 days interval for 45 days) of the compound. The compound cleared the amastigotes form of the parasite from the liver and spleen of infected animals with a mechanism that involves decrease in the expression of mRNA for anti-inflammatory cytokines [interleukin (IL)-10 and IL-4] and an increase in the level of interferon- $\gamma$ (IFN- $\gamma$ ) and tumor necrosis factors alpha (TNF- $\alpha$ ) (Ukil et al. 2005). This comprehensively resulted in an increased immune response to the infection and clearance of the parasite via an nuclear factor kappa-B (NF- $\kappa \mathrm{B})$-mediated mechanism. The mechanism through which GRA upregulate $\mathrm{NF}-\kappa \mathrm{B}$ was further described to involve multiple kinases and phosphatases (Ukil et al. 2011). Indeed, stimulation of the immune system has been deemed a rational strategy for the development of anti-leishmanial drugs (Santos et al. 2008). In a different study, oral and intraperitoneal administration of $10 \mathrm{mg} \mathrm{kg}^{-1}$ bw DHBA to infected golden hamsters caused $>90 \%$ reduction in parasite load in the spleen and liver of the infected animals. The compound was proposed to exert its effect via a mechanism that involves inhibition of DNA topoisomerases thereby essentially destroying the parasites 
(Chowdhury et al. 2003, 2011). As observed with other PT, the chemical entities on the C3 and C28 position of the lupeol-type PT is critical for the anti-parasitic activity of the group. Further analysis of the existing members of the group and structural manipulations to enhance activity is recommended.

\section{Anti-nematodal activities of PTs}

P'Ts were also investigated in a number of studies as possible therapeutic agents against lymphatic filariasis, onchocerciasis as well as conditions caused by other parasitic nematodes. Antifilarial activities of oleanane PT were reported against both human lymphatic filaria Brugia malayi and the rodent infective species. Oleanonic acid (66) and OA (13) isolated from the stem of Lantana camara were active against $B$. malayi in vitro with an $\mathrm{LC}_{100}$ of $31 \cdot 25$ and $62 \cdot 50 \mu \mathrm{g} \mathrm{mL}^{-1}$ respectively (Misra et al. 2007). Glycyrrhetinic acid (33) and its analogs (34-37) were also shown to be effective against the adult and microfilarial forms of B. malayi. The acyl derivatives (38 and 39) were inactive against both growth stages of the parasite, while the others showed $\mathrm{IC}_{50}$ values in the of $0 \cdot 56-28.63 \mu \mathrm{g} \mathrm{mL}-1$ range against the microfilariae. However, against the adult worms, only the benzyl amide (34) and octyl amide (35) derivatives were active $\left(\mathrm{IC}_{50} \quad 5.95\right.$ and $12.04 \mu \mathrm{g} \mathrm{mL}^{-1}$ respectively) (Kalani et al. 2013).

In animal studies, the OA and oleanonic acid each administered at oral and intraperitoneal doses of 200 and $100 \mathrm{mg} \mathrm{kg}^{-1}$ bw respectively had no effect on the circulating microfilariae of $B$. malayi in infected mastomys. However, against the adult worms, both compounds showed approximately $56 \%$ female worm sterility, although only OA had a filaricidal activity of $18 \cdot 18 \%$ (Misra et al. 2007). Moreover, B. malayi infected jirds were treated with $100 \mathrm{mg} \mathrm{kg}^{-1} \mathrm{bw}$ doses of the in vitro active amide derivatives of GRA (34 and 35). The result showed that only the benzyl amide derivative possessed macrofilaricidal activity (54\%) while the other was inactive (Kalani et al. 2013).

The oleanane-type PT, 3-O-acetyl aleuritolic acid (75) isolated from Discoglypremna caloneura was active against Onchorcerca gutturosa worms. The compound was found to reduce the motility and viability of the worms up to $57 \cdot 1$ and $64 \cdot 8 \%$, respectively. The reduction in viability was found to be $33 \cdot 3 \%$ more than that of amocarzine and hence compound 75 was considered an interesting compound against filarial infections (Nyasse et al. 2006).

Although the volume of research on the antifilarial activities of PT is not large, available data suggest them to be potent against different filariid. Hence, future screening of other P'T against filariasis may be worthwhile.

Betulin (134) from Schefflera vinosa as well as $\mathrm{OA}$ and UA from Miconia langsdorfii were tested for schistomicidal activities. Among the three compounds, only 134 led to the mortality of the adult worms of Schistosoma mansonii at concentrations of $100 \mu \mathrm{M}(25 \%$ mortality) and $200 \mu \mathrm{M}(50 \%)$ after $120 \mathrm{~h}$ of incubation (Cunha et al. 2012). Further research on this subject area should focus on testing newly isolated and available PT on different species of Schistosoma to compliment the library of biological activities of the group as future anti-parasitic agents.

OA isolated from Calendula officinalis was investigated for possible nematocidal activity against the mice intestinal parasite, Heligmosomoides polygyrus. The compound alongside other derivatives exhibited $>50 \%$ growth inhibition of the larvae incubated with $70 \mu \mathrm{g} \mathrm{mL}{ }^{-1}$ of the compounds in vitro. The mechanism through which OA and related PT reduces the viability of $H$. polygyrus was later shown to involve modulation of the pattern of larval antigen glycosylation which appears to lead to a robust increase in cytokine production in mice infected with larvae incubated with the compound (Doligalska et al. 2013). Because anti-filarials act via an immunemediated mechanisms (Hoerauf et al. 2011), and PTs were shown to modulate the immune system, P'Ts are logical candidates for in vivo screening as anti-filarial drugs.

MA was also investigated for possible action against the Trichinella, the causative agent of trichinellosis in humans. Against the mammalian infective Trichinella zimbabwensis, the compound orally administered once on $25 \mathrm{dpi}$ or twice on 25 and 32 dpi cleared $>90 \%$ of the parasite's larvae. This was achieved at a lower dose $\left(2 \cdot 5 \mathrm{mg} \mathrm{kg}^{-1} \mathrm{bw}\right)$ compared with the anthelmic drug fenbendazole $\left(7 \cdot 5 \mathrm{mg} \mathrm{kg}^{-1}\right.$ bw) which gave similar efficacy (Mukaratirwa et al. 2016). Hence, MA has shown promising activity against Trichinella and therefore screening of other PT against this parasite will be worthwhile.

Against the plant nematode Meloidogyne incognita, camarinic acid (110) activity was similar to that of a standard nematicidal drug, furadan, at the same concentration of $1 \mathrm{mg} \mathrm{mL}^{-1}$. The compound which was isolated from Lantana camara led to $100 \%$ larval mortality after $24 \mathrm{~h}$ exposure (Supplementary Table S1, available from http://journals.cambridge. org/PAR) (Begum et al. 2000). Later studies on this plant showed it to be a repository of PT with varying degrees of nematicidal activities. Lantanilic acid (46), camaric acid (45) and OA (13) from the plant caused 98,95 and $70 \% M$. incognita larval mortality respectively at $5 \mathrm{mg} \mathrm{mL}^{-1}$ concentration (Qamar et al. 2005). Furthermore, camarinin (43), lantanolic acid (44), UA, pomolic acid (100), lantacin (114), camarin (77) and lantoic acid (111) from the same plant all caused $100 \%$ larval mortality at $1 \mathrm{mg} \mathrm{mL}{ }^{-1}$ concentration after $48 \mathrm{~h}$ of exposure. Compounds 43,44 and UA $(88)$ proved to be comparatively more potent with 90,10 and $10 \%$ larval mortality at $2 \mu \mathrm{g} \mathrm{mL}^{-1}$ after $72 \mathrm{~h}$ exposure (Begum 
et al. 2008). In a different study with Cordia latifolia, cordinoic acid (112) isolated from the plant at $5 \mathrm{mg}$ $\mathrm{mL}^{-1}$ concentration led to $100 \%$ M. incognita larval mortality after $24 \mathrm{~h}$ exposure (Begum et al. 2011). On the other hand, polygalacic acid $(48)$ and bayogenin (49) and their saponins 50-60 isolated from Microsechium helleri and Sicyos bulbosus were active against Meloidogyne javanica that also affects plants. Among the compounds, those with a xylose residue attached to the second rhamnose residue at the substituent on $\mathrm{C} 28$ (50-53) were found to be inactive while the others inhibited $>74 \%$ of the parasite's larvae growth at various concentrations. Moreover, bayogenin which differs from polygalacic acid only in the absence of an $\mathrm{OH}$ group at $\mathrm{C} 16$ of the latter molecule was the most active together with saponin 58. Both compounds immobilized $100 \%$ of the parasite's larvae at $0.5 \mu \mathrm{g} \mathrm{mL}^{-1}$ concentration (Hernández-Carlos et al. 2011). From the above findings, it is clear that the activities of PT and their saponin against plant nematodes are promising and warrant further investigation.

\section{Activities of PTs against other parasites}

Toxoplasma: Maslinic acid (61) isolated from Olea europaea inhibited the infectivity of Vero cells by $T$. gondii tachyzoites with an $\mathrm{ID}_{50}$ of $3.78 \mu \mathrm{g} \mathrm{mL}^{-1}$ after incubation for $48 \mathrm{~h}$. Moreover, the compound at a concentration of $50 \mu \mathrm{M}$ inhibited the motility of $100 \%$ of the parasites. The compound was also shown to inhibit key parasite proteases thereby effectively blocking parasite entry into the cells (De Pablos et al. 2010). This dual effect (inhibition of motility and entrance into cells) of MA on $T$. gondii is interesting as therapeutic approach and hence calls for further screening alongside other PT.

Trichomonas: Only one PT, hederagenin (47), isolated from Cussonia holstii was investigated for activity against Trichomonas viginalis. The result indicated high in vitro activity with an $\mathrm{IC}_{50}$ of $1.32 \mu \mathrm{g} \mathrm{mL}^{-1}$ (He et al. 2003). Hence, PT could be suitable candidates for future screening as anti-trichomonas agents.

\section{Toxicity aspects}

One of the disadvantages of using PT as therapeutic agents has been known to be associated with high cytotoxicity (Dzubak et al. 2006). However, at low concentrations, some of these PT have proved to be therapeutic (Liu, 2005). Moreover, cytotoxicity studies of some PT, for example MA, reported in vivo safety both in acute and chronic treatments (Sánchez-González et al. 2013). In another study, BA was found to have selective toxicity against cancerous cells but not normal cells (Zuco et al. 2002). Hence, since PT are selective to different cells lines, further toxicity assessments and in vivo safety studies of the most active compounds is warranted.
CONCLUSION AND FUTURE DIRECTIONS

Various research findings from plants of different parts of the world have revealed that PT represent a promising group of phytochemicals with good therapeutic potential against a number of parasitic diseases. However, the studies on the anti-parasitic potential of PT are at preliminary proof of concept stages with only 22 out of the total 191 PT having been investigated in animal models. This underscores the need to re-focus research efforts on in vivo studies of $\mathrm{PT}$ against different parasitic infections which may pave the way for further clinical trials and drug development.

On a general note, it is noteworthy that the PT seems to be more promising for future development as anti-malarial agents. This is evident by the propensity of anti-plasmodial studies of PT as well as the potent activities reported for most of the tested PT. However, this does not exclude the possibility of developing therapeutically active PT against other parasites, especially the less studied parasites such as toxoplasma, trichomonas, schistosoma and nematodes.

Another pertinent finding from this review is that quinine methides are the most biologically potent PT with respect to parasitic diseases especially those caused by malaria parasites. Unfortunately however, this class of the compounds also seems to be the most toxic among all the PTs. Thus, studies on quinine methides to target synthetic modifications at various positions of the parent backbone with the aim of minimizing their cytotoxicity, whilst maintaining the anti-parasitic activities should be conducted. In fact, this should be the next step to be taken if research efforts on quinine methides are to be geared along the drug development process.

\section{SUPPLEMENTARY MATERIAL}

The supplementary material for this paper can be found at http://dx.doi.org/10.1017/S00311820 16000718

\section{ACKNOWLEDGEMENTS}

We wish to acknowledge a PhD study fellowship awarded to MBI by the TETFund desk office of Umaru Musa Yar'adua University Katsina, Nigeria.

\section{REFERENCES}

Abe, F., Yamauchi, T., Nagao, T., Kinjo, J., Okabe, H., Higo, H. and Akahane, H. (2002). Ursolic acid as a trypanocidal constituent in rosemary. Biological and Pharmaceutical Bulletin 25, 1485-1487.

Alves, T. M. D. A., Nagem, T. J., de Carvalho, L. H., Krettli, A. U. and Zani, C. L. (1997). Antiplasmodial triterpene from Vernonia brasiliana. Planta Medica 63, 554-555.

Begum, S., Wahab, A., Siddiqui, B.S. and Qamar, F. (2000). Nematicidal constituents of the aerial parts of Lantana camara. Fournal of Natural Products 63, 765-767.

Begum, S., Zehra, S. Q., Siddiqui, B. S., Fayyaz, S. and Ramzan, M. (2008). Pentacyclic triterpenoids from the aerial parts of Lantana camara and their nematicidal activity. Chemistry and Biodiversity 5, 1856-1866. 
Begum, S., Perwaiz, S., Siddiqui, B.S., Khan, S., Fayyaz, S. and Ramzan, M. (2011). Chemical constituents of Cordia latifolia and their nematicidal activity. Chemistry \& Biodiversity 8, 850-861.

Bero, J., Hannaert, V., Chataigné, G., Hérent, M.F. and QuetinLeclercq, J. (2011). In vitro antitrypanosomal and antileishmanial activity of plants used in Benin in traditional medicine and bio-guided fractionation of the most active extract. Fournal of Ethnopharmacology 137, 998-1002. Bhutta, Z. A., Sommerfeld, J., Lassi, Z. S., Salam, R. A. and Das, J. K. (2014). Global burden, distribution and interventions for the infectious diseases of poverty. Infectious Diseases of Poverty 3, 21.

Broniatowski, M., Flasiński, M. and Wydro, P. (2012). Investigation of the interactions of lupane type pentacyclic triterpenes with outer leaflet membrane phospholipids - Langmuir monolayer and synchrotron X-ray scattering study. Fournal of Colloid and Interface Science 381, 116-124.

Buckner, F. S., Waters, N. C. and Avery, V. M. (2012). Recent highlights in anti-protozoan drug development and resistance research. International Fournal for Parasitology: Drugs and Drug Resistance 2, 230-235.

Camacho, M. D. R., Mata, R., Castaneda, P., Kirby, G. C., Warhurst, D. C., Croft, S. L. and Phillipson, J. D. (2000). Bioactive compounds from Celaenodendron mexicanum. Planta Medica 66, 463-468.

Chowdhury, A. R., Mandal, S., Goswami, A., Ghosh, M., Mandal, L., Chakraborty, D., Ganguly, A., Tripathi, G., Mukhopadhyay, S., Banyopadhyay, S. and Majumder, H. K. (2003). Dihydrobetulinic acid induces apoptosis in Leishmania donovani by targeting DNA topoisomerase I and II: implications in antileishmanial therapy. Molecular Medicine 9, 26-36

Chowdhury, S., Mukherjee, T., Sengupta, S., Chowdhury, S. R., Mukhopadhyay, S. and Majumder, H. K. (2011). Novel betulin derivatives as antileishmanial agents with mode of action targeting type IB DNA topoisomerase. Molecular Pharmacology 80, 694-703.

Cunha, W. R., Crevelin, E. J., Arantes, G. M., Crotti, A. E. M., Silva, M. L., Furtado, N. A., Albuquerque, S. and Ferreira, D. D. S. (2006). A study of the trypanocidal activity of triterpene acids isolated from Miconia species. Phytotherapy Research 20, 474-478.

Cunha, W. R., Martins, C., Ferreira, D. D., Crotti, A. E., Lopes, N. P. and Albuquerque, S. (2003). In vitro trypanocidal activity of triterpenes from Miconia species. Planta Medica 69, 470-471.

Cunha, N. L., Uchôa, C. J. D., Cintra, L. S., de Souza, H. C., Peixoto, J. A., Silva, C.P., Magalhaes, L. G., Gimenez, V.M.M., Groppo, M., Rodriguez, V., da Silva Filho, A. A., e Silva, M. L. A., Cunha, W. R., Pauletti, P. M. and Januário, A. H. (2012). In vitro schistosomicidal activity of some Brazilian cerrado species and their isolated compounds. Evidence-Based Complementary and Alternative Medicine 2012, 173614 .

da Silva Ferreira, D., Esperandim, V. R., Toldo, M. P. A., Saraiva, J., Cunha, W. R. and De Albuquerque, S. (2010). Trypanocidal activity and acute toxicity assessment of triterpene acids. Parasitology Research 106, 985-989.

da Silva Ferreira, D., Esperandim, V. R., Toldo, M. P. A., Kuehn, C. C., do Prado Junior, J. C., Cunha, W. R. and Albuquerque, S. D. (2013a). In vivo activity of ursolic and oleanolic acids during the acute phase of Trypanosoma cruzi infection. Experimental Parasitology 134, 455-459.

da Silva Ferreira, D., Esperandim, V. R., Marçal, M. G., Neres, N. B. R., Cunha, N. L., Silva, M. L. A. and Cunha, W. R. (2013b). Natural products and Chagas' disease: the action of triterpenes acids isolated from Miconia species. Universitas Scientiarum 18, 243-256.

da Silva Filho, A. A., Bueno, P.C.P., Gregório, L. E., Silva, M. L., Albuquerque, S. and Bastos, J. K. (2004). In-vitro trypanocidal activity evaluation of crude extract and isolated compounds from Baccharis dracunculifolia DC (Asteraceae). Fournal of Pharmacy and Pharmacology 56, 11951199.

da Silva Filho, A.A., Resende, D. O., Fukui, M. J., Santos, F.F., Pauletti, P. M., Cunha, W. R., Silva, M. L.A., Gregório, L. E., Bastos, J. K. and Nanayakkara, N. P. D. (2009). In vitro antileishmanial, antiplasmodial and cytotoxic activities of phenolics and triterpenoids from Baccharis dracunculifolia DC (Asteraceae). Fitoterapia 80, 478-482.

De Pablos, L. M., González, G., Rodrigues, R., García Granados, A., Parra, A. and Osuna, A. (2010). Action of a pentacyclic triterpenoid, maslinic acid, against Toxoplasma gondii. Fournal of Natural Products 73, 831-834. de Sá, M. S., Costa, J. F. O., Krettli, A. U., Zalis, M. G., de Azevedo Maia, G. L., Sette, I. M. F., Câmara, C. D., da Silva Filho, J. M. B., Giulietti-Harley, A. M., dos Santos, R. R. and Soares, M. B.P. (2009). Antimalarial activity of betulinic acid and derivatives in vitro against Plasmodium falciparum and in vivo in P. berghei-infected mice. Parasitology Research 105, 275-279.

Doligalska, M., Joźwicka, K., Laskowska, M., DonskowLysoniewska, K., Pączkowski, C. and Janiszowska, W. (2013).
Changes in Heligmosomoides polygyrus glycoprotein pattern by saponins impact the BALB/c mice immune response. Experimental Parasitology 135, 524-531.

Dzubak, P., Hajduch, M., Vydra, D., Hustova, A., Kvasnica, M., Biedermann, D., Markoba, L., Urban, M. and Sarek, J. (2006). Pharmacological activities of natural triterpenoids and their therapeutic implications. Natural Product Reports 23, 394-411

Figueiredo, J. N., Räz, B. and Séquin, U. (1998). Novel quinone methides from Salacia kraussii with in vitro antimalarial activity. Fournal of Natural Products 61, 718-723.

Gachet, M. S., Kunert, O., Kaiser, M., Brun, R., Zehl, M., Keller, W. Munoz, R. A., Bauer, R. and Schuehly, W. (2011). Antiparasitic compounds from Cupania cinerea with activities against Plasmodium falciparum and Trypanosoma brucei rhodesiense. Fournal of Natural Products 74, 559-566.

Germonprez, N., Maes, L., Van Puyvelde, L., Van Tri, M., Tuan, D. A. and De Kimpe, N. (2005). In vitro and in vivo anti-leishmanial activity of triterpenoid saponins isolated from Maesa $\mathrm{b}$ alansae and some chemical derivatives. Fournal of Medicinal Chemistry 48, 32-37.

Gnoatto, S. C., Vechia, L. D., Lencina, C. L., Dassonville-Klimpt, A., Da Nascimento, S., Mossalayi, D., Gullon, J., Gosmann, G. and Sonnet, P. (2008). Synthesis and preliminary evaluation of new ursolic and oleanolic acids derivatives as antileishmanial agents. Fournal of Enzyme Inhibition and Medicinal Chemistry 23, 604-610.

Graziose, R., Rojas-Silva, P., Rathinasabapathy, T., Dekock, C., Grace, M. H., Poulev, A., Lila, M. A., Smith, P. and Raskin, I. (2012). Antiparasitic compounds from Cornus florida L. with activities against Plasmodium falciparum and Leishmania tarentolae. Fournal of Ethnopharmacology 142, 456-461

Güçlü-Üstündağ, Ö. and Mazza, G. (2007). Saponins: properties, applications and processing. Critical Reviews in Food Science and Nutrition 47, 231-258.

He, W., Van Puyvelde, L., Maes, L., Bosselaers, J. and De Kimpe, N. (2003). Antitrichomonas in vitro activity of Cussonia holstii Engl. Natural Product Research 17, 127-133

He, Z. D., Ma, C. Y., Zhang, H. J., Tan, G. T., Tamez, P., Sydara, K., Bouamanivong, S., Southavong, B., Soejarto, D. D., Pezzuto, J. M. and Fong, H. H. (2005). Antimalarial constituents from Nauclea orientalis (L.) L. Chemistry and Biodiversity 2, 1378-1386.

Hernández-Carlos, B., González-Coloma, A., Orozco-Valencia, Á. U., Ramírez-Mares, M. V., Andrés-Yeves, M. F. and JosephNathan, P. (2011). Bioactive saponins from Microsechium helleri and Sicyos bulbosus. Phytochemistry 72, 743-751.

Hill, R. A. and Connolly, J. D. (2015). Triterpenoids. Natural Product Reports 32, 273-327.

Hoerauf, A., Pfarr, K., Mand, S., Debrah, A. Y. and Specht, S. (2011). Filariasis in Africa - treatment challenges and prospects. Clinical Microbiology and Infection 17, 977-985.

Hoet, S., Pieters, L., Muccioli, G. G., Habib-Jiwan, J. L., Opperdoes, F. R., and Quetin-Leclercq, J. (2007). Antitrypanosomal activity of triterpenoids and sterols from the leaves of Strychnos spinosa and related compounds. Fournal of Natural Products 70, 1360-1363.

Hotez, P. J., Alvarado, M., Basáñez, M. G., Bolliger, I., Bourne, R., Boussinesq, M., Brooker, S. J., Brown, A. S., Buckle, G., Budke, C. M., Carabin, H., Coffeng, L. E., Fèvre, E. M., Fürst, T., Halasa, Y. A., Jasrasaria, R., Johns, N. E., Keiser, J., King, C. H., Lozano, R., Murdoch, M. E., O'Hanlon, S., Pion, S. D.S., Pullan, R. L., Ramaiah, K. D., Roberts, T., Shepard, D. S., Smith, J. L., Stolk, W. A., Undurraga, E. A., Utzinger, J., Wang, M., Murray, C. J. L. and Naghavi, M. (2014). The Global Burden of Disease Study 2010: interpretation and implications for the neglected tropical diseases. PLoS Neglected Tropical Diseases 8, e2865.

Ibrahim, M. A., Mohammed, A., Isah, M. B. and Aliyu, A. B. (2014) Anti-trypanosomal activity of African medicinal plants: a review update. 7ournal of Ethnopharmacology 154, 26-54.

Izumi, E., Ueda-Nakamura, T., Dias Filho, B. P., Júnior, V. F. V. and Nakamura, C. V. (2011). Natural products and Chagas' disease: a review of plant compounds studied for activity against Trypanosoma cruzi. Natural Product Reports 28, 809-823.

Jäger, S., Trojan, H., Kopp, T., Laszczyk, M. N. and Scheffler, A. (2009). Pentacyclic triterpene distribution in various plants - rich sources for a new group of multi-potent plant extracts. Molecules 14, 2016-2031. Kalani, K., Kushwaha, V., Verma, R., Murthy, P. K. and Srivastava, S. K. (2013). Glycyrrhetinic acid and its analogs: a new class of antifilarial agents Bioorganic and Medicinal Chemistry Letters 23, 2566-2570.

Laszczyk, M. N. (2009). Pentacyclic triterpenes of the lupane, oleanane and ursane group as tools in cancer therapy. Planta Medica 75, 1549-1560. 
Leder, K., Torresi, J., Brownstein, J. S., Wilson, M. E., Keystone, J. S., Barnett, E., Schwartz, E., Schlagenhauf, P., Wilder-Smith, A., Castelli, F., von Sonnenburg, F., Freedman, D. O. and Cheng, A. C. (2013). Travel-associated illness trends and clusters, 2000-2010. Emerging Infectious Diseases 19, 1049-1057.

Leite, A. C., Ambrozin, A. R.P., Fernandes, J. B., Vieira, P. C., Silva, M. F. G. F. and Albuquerque, S. D. (2008). Trypanocidal activity of limonoids and triterpenes from Cedrela fissilis. Planta Medica 74, 17951799 .

Lenta, B. N., Ngouela, S., Boyom, F. F., Tantangmo, F., Tchouya, G. F., Tsamo, E., Gut, J., Rosenthal, P. J. and Connolly, J. D. (2007). Antiplasmodial activity of some constituents of the root bark of Harungana madagascariensis LAM. (Hypericaceae). Chemical and Pharmaceutical Bulletin (Tokyo) 55, 464-467.

Liu, J. (2005). Oleanolic acid and ursolic acid: research perspectives. Fournal of Ethnopharmacology 100, 92-94.

Ma, C. Y., Musoke, S. F., Tan, G. T., Sydara, K., Bouamanivong, S., Southavong, B., Soejarto, D. D., Fong, H.H.S. and Zhang, H. J. (2008). Study of antimalarial activity of chemical constituents from Diospyros quaesita. Chemistry and Biodiversity 5, 2442-2448.

Maes, L., Germonprez, N., Quirijnen, L., Van Puyvelde, L., Cos, P. and Berghe, D. V. (2004). Comparative activities of the triterpene saponin maesabalide III and liposomal amphotericin B (AmBisome) against Leishmania donovani in hamsters. Antimicrobial Agents and Chemotherapy 48, 2056-2060.

Maregesi, S. M., Hermans, N., Dhooghe, L., Cimanga, K., Ferreira, D., Pannecouque, C., Vanden Berghee, D. A., Cose, P. Maese, L., Vlietincka, A. J., Apersa, S. and Pieters, L. (2010). Phytochemical and biological investigations of Elaeodendron schlechteranum. Fournal of Ethnopharmacology 129, 319-326.

Misra, N., Sharma, M., Raj, K., Dangi, A., Srivastava, S. and MisraBhattacharya, S. (2007). Chemical constituents and antifilarial activity of Lantana camara against human lymphatic filariid Brugia malayi and rodent filariid Acanthocheilonema viteae maintained in rodent hosts. Parasitology Research 100, 439-448.

Mohanty, S., Srivastava, P., Maurya, A. K., Cheema, H.S., Shanker, K., Dhawan, S., Darokar, M.P. and Bawankule, D. U. (2013). Antimalarial and safety evaluation of Pluchea lanceolato (DC.) Oliv. and Hiern: in-vitro and in-vivo study. Fournal of Ethnopharmacology 149, 797-802.

Moneriz, C., Marín-García, P., Bautista, J. M., Diez, A. and Puyet, A. (2011a). Parasitostatic effect of maslinic acid. II. Survival increase and immune protection in lethal Plasmodium yoelii-infected mice. Malaria Fournal 10, 103.

Moneriz, C., Marín-García, P., García-Granados, A., Bautista, J. M., Diez, A. and Puyet, A. (2011b). Parasitostatic effect of maslinic acid. I. Growth arrest of Plasmodium falciparum intraerythrocytic stages. Malaria fournal 10, 82.

Moneriz, C., Mestres, J., Bautista, J. M., Diez, A. and Puyet, A. (2011c). Multi-targeted activity of maslinic acid as an antimalarial natural compound. FEBS Fournal 278, 2951-2961.

Moon, H. I., Jung, J. C. and Lee, J. (2007). Antiplasmodial activity of triterpenoid isolated from whole plants of Viola genus from South Korea. Parasitology Research 100, 641-644.

Mukaratirwa, S., Gcanga, L. and Kamau, J. (2016). Efficacy of maslinic acid and fenbendazole on muscle larvae of Trichinella zimbabwensis in laboratory rats. Fournal of Helminthology 90, 86-90.

Newman, D. J. and Cragg, G. M. (2012). Natural products as sources of new drugs over the 30 years from 1981 to 2010. Fournal of Natural Products 75, 311-335.

Nyasse, B., Ngantchou, I., Nono, J. J. and Schneider, B. (2006). Antifilarial activity in vitro of polycarpol and 3-O-acetyl aleuritolic acid from Cameroonian medicinal plants against Onchocerca gutturosa. Natural Product Research 20, 391-397.

Nyongbela, K. D., Lannang, A. M., Ayimele, G. A., Ngemenya, M. N., Bickle, Q. and Efange, S. (2013). Isolation and identification of an antiparasitic triterpenoid estersaponin from the stem bark of Pittosporum mannii (Pittosporaceae). Asian Pacific Fournal of Tropical Disease 3, 389-392.

Pink, R., Hudson, A., Mouriès, M. A. and Bendig, M. (2005). Opportunities and challenges in antiparasitic drug discovery. Nature Reviews Drug Discovery 4, 727-740.

Qamar, F., Begum, S., Raza, S. M., Wahab, A. and Siddiqui, B.S. (2005). Nematicidal natural products from the aerial parts of Lantana camara Linn. Natural Product Research 19, 609-613.

Rasoanaivo, P., Wright, C. W., Willcox, M. L. and Gilbert, B. (2011). Whole plant extracts versus single compounds for the treatment of malaria: synergy and positive interactions. Malaria fournal 10, S4.
Ridoux, O., Di Giorgio, C., Delmas, F., Elias, R., Mshvildadze, V., Dekanosidze, G., Kemertelidze, E., Balansard, G. and TimonDavid, P. (2001). In vitro antileishmanial activity of three saponins isolated from ivy, $\alpha$-hederin, $\beta$-hederin and hederacolchiside A1, in association with pentamidine and amphotericin B. Phytotherapy Research 15, 298-301.

Rocha, L. G., Almeida, J.R. G.S., Macedo, R. O. and BarbosaFilho, J. M. (2005). A review of natural products with antileishmanial activity. Phytomedicine 12, 514-535.

Ruphin, F. P., Baholy, R., Emmanue, A., Amelie, R., Martin, M. T. and Koto-te-Nyiwa, N. (2013). Antiplasmodial, cytotoxic activities and characterization of a new naturally occurring quinone methide pentacyclic triterpenoid derivative isolated from Salacia leptoclada Tul. (Celastraceae) originated from Madagascar. Asian Pacific Fournal of Tropical Biomedicine 3, 780-784.

Safayhi, H. and Sailer, E. R. (1997). Anti-inflammatory actions of pentacyclic triterpenes. Planta Medica 63, 487-493.

Sairafianpour, M., Bahreininejad, B., Witt, M., Ziegler, H. L., Jaroszewski, J. W. and Stærk, D. (2003). Terpenoids of Salvia hydrangea: two new, rearranged 20-norabietanes and the effect of oleanolic acid on erythrocyte membrane. Planta Medica 69, 846-850.

Sánchez-González, M., Lozano-Mena, G., Juan, M. E., GarcíaGranados, A. and Planas, J. M. (2013). Assessment of the safety of maslinic acid, a bioactive compound from Olea europaea L. Molecular Nutrition and food Research 57, 339-346.

Santos, D. O., Coutinho, C. E., Madeira, M.F., Bottino, C. G., Vieira, R. T., Nascimento, S. B., Bernardino, A., Bourguignon, S. C., Corte-Real, S., Pinho, R. T., Rodrigues, C. R. and Castro, H. C. (2008). Leishmaniasis treatment - a challenge that remains: a review. Parasitology Research 103, 1-10.

Sheng, H., and Sun, H. (2011). Synthesis, biology and clinical significance of pentacyclic triterpenes: a multi-target approach to prevention and treatment of metabolic and vascular diseases. Natural Product Reports 28, 543-593.

Simelane, M. B., Shonhai, A., Shode, F. O., Smith, P., Singh, M. and Opoku, A. R. (2013). Anti-plasmodial activity of some Zulu Medicinal plants and of some triterpenes isolated from them. Molecules 18, 1231312323 .

Steele, J. C. P., Warhurst, D. C., Kirby, G. C. and Simmonds, M. S. J. (1999). In vitro and in vivo evaluation of betulinic acid as antimalarial. Phytotherapy Research 13, 115-119.

Suksamrarn, A., Tanachatchairatana, T. and Kanokmedhakul, S. (2003). Antiplasmodial triterpenes from twigs of Gardenia saxatilis. Fournal of Ethnopharmacology 88, 275-277.

Taketa, A. T., Gnoatto, S. C., Gosmann, G., Pires, V. S., Schenkel, E. P. and Guillaume, D. (2004). Triterpenoids from Brazilian Ilex species and their in vitro antitrypanosomal activity. Fournal of Natural Products 67, 1697-1700

Tan, N., Kaloga, M., Radtke, O.A., Kiderlen, A. F., Öksüz, S., Ulubelen, A. and Kolodziej, H. (2002). Abietane diterpenoids and triterpenoic acids from Salvia cilicica and their antileishmanial activities. Phytochemistry 61, 881-884.

Tantangmo, F., Lenta, B. N., Boyom, F. F., Ngouela, S., Kaiser, M., Tsamo, E., Weniger, B., Rosenthal, P.J. and VonthronSenecheau, C. (2010). Antiprotozoal activities of some constituents of Markhamia tomentosa (Bignoniaceae). Annals of Tropical Medicine and Parasitology 104, 391-398.

Tarleton, R. L. (2007). Immune system recognition of Trypanosoma cruzi. Current Opinion in Immunology 19, 430-434.

Torres-Santos, E. C., Lopes, D., Rodrigues Oliveira, R., Carauta, J. P. P., Bandeira Falcao, C. A., Kaplan, M. A. C. and Rossi-Bergmann, B. (2004). Antileishmanial activity of isolated triterpenoids from Pourouma guianensis. Phytomedicine 11, 114-120.

Ukil, A., Biswas, A., Das, T. and Das, P. K. (2005). 18 $\beta$-glycyrrhetinic acid triggers curative Th1 response and nitric oxide up-regulation in experimental visceral leishmaniasis associated with the activation of NF$\kappa$ B. Fournal of Immunology 175, 1161-1169.

Ukil, A., Kar, S., Srivastav, S., Ghosh, K. and Das, P. K. (2011). Curative effect of $18 \beta$-glycyrrhetinic acid in experimental visceral leishmaniasis depends on phosphatase-dependent modulation of cellular MAP kinases. PLoS ONE 6, e29062.

Vincken, J.P., Heng, L., de Groot, A. and Gruppen, H. (2007). Saponins, classification and occurrence in the plant kingdom. Phytochemistry 68, 275-297.

Wolska, K. I., Grudniak, A. M., Fiecek, B., KraczkiewiczDowjat, A. and Kurek, A. (2010). Antibacterial activity of oleanolic and ursolic acids and their derivatives. Central European Fournal of Biology 5, 543-553. 
Wright, C. W. (2010). Recent developments in research on terrestrial plants used for the treatment of malaria. Natural Product Reports 27, 961-968.

Xu, R., Fazio, G. C. and Matsuda, S. P. (2004). On the origins of triterpenoid skeletal diversity. Phytochemistry 65, 261-291.

Ziegler, H. L., Franzyk, H., Sairafianpour, M., Tabatabai, M., Tehrani, M.D., Bagherzadeh, K., Hägerstrand, H., Stærk, D. and Jaroszewski, J. W. (2004). Erythrocyte membrane modifying agents and the inhibition of Plasmodium falciparum growth: structure-activity relationships for betulinic acid analogues. Bioorganic and Medicinal Chemistry 12, 119-127.

Ziegler, H. L., Staalsø, T. and Jaroszewski, J. W. (2006). Loading of erythrocyte membrane with pentacyclic triterpenes inhibits Plasmodium falciparum invasion. Planta Medica 72, 640-642.

Zuco, V., Supino, R., Righetti, S. C., Cleris, L., Marchesi, E., Gambacorti-Passerini, C. and Formelli, F. (2002). Selective cytotoxicity of betulinic acid on tumor cell lines, but not on normal cells. Cancer Letters $175,17-25$. 